\title{
Guidelines on Halal Tourism Management in the Andaman Sea Coast of Thailand
}

\author{
Oraphan Chanin, Piangpis Sriprasert, Hamzah Abd Rahman, and Mohd Sobri Don
}

\begin{abstract}
The purposes of the research were to:1) evaluate the potential of existing Halal tourist places and to rank them; 2) examine (current) Halal tourism management practices in the Andaman Sea coast of Thailand catering for travelers from Muslim countries and; 3) propose feasible guidelines on Halal tourism management in this area. The sample groups were government officers working in the tourism-related sections, administrators in the sub-district administrative organization offices in the provinces along the Andaman Sea coast, community leaders, tour guides, officers of the provincial offices of the Islamic Council in the Andaman Sea coast, Muslim tourists from Muslim countries and officers of the Central Islamic Council of Thailand. The research instruments included a questionnaire, observations and focus group discussions. The findings suggests that Halal tourism operators must provide prayer rooms for Muslim tourists as well as the direction signs to the mosque either in English or Arabic, separate restrooms for men and women. In addition, Halal restaurants should be provided in tourist attraction areas.
\end{abstract}

Index Terms-Guidelines on Halal tourism, Halal tourism management, Andaman Sea Coast of Thailand.

\section{INTRODUCTION}

Nowadays, the tourism industry is one of the world's largest and fastest growing economic sectors. Tourism is seen as a key sector that can bring jobs and earn hard currency, supported igneous sectors, spread of infrastrucstructures and support for an outward oriented growth strategy enabling developing nations to join the global economy. It is also an effective tool of economic development that may offset economic hardships, and also can be used forestrucuring in a liberalized global economy [1].

Tourism is one of the most important sectors of the Thai economy with highest earning of foreign exchange [2]. Thailand has great diversity in tourism resources; especially in geography, climates, biology and flora \& fauna. This encourages an increasing number of both and biodiversity. Thai and international tourists are able to visit many provinces of Thailand. Also, Thailand has a good reputation in cultural tourism. The Government of Thailand is continually promoting the development of tourism in various tourist destinations throughout the country [2].

Halal Tourism is a market segment that is fast growing not

Manuscript received November 10, 2013; revised January 20, 2014.

Oraphan Chanin is with the Rajamangala University of Technology Srivijaya, Thailand (e-mail: or_chanin@yahoo.com).

Piangpis Sriprasert is with the Nakhon Si Thammarat Rajabhat University, Thailand.

Hamzah Abd Rahman and Mohd Sobri Don are with the University Utara Malaysia, Kedah, Malaysia. only in Muslim countries but globally. Non-Muslim countries like Australia, Taiwan, Korea, Japan, countries in Europe, are specifically catering for the Islamic tourism segment. There are close to 1.7 billion Muslims worldwide who are becoming more affluent and regularly traveling with their families and friends. It used to be that Muslims travelled overseas for Hajj and Umrah. Now they have learned to take time to travel for leisure. It is easier to find Halal food in non-Muslim countries; hotels are also trying to meet Muslim travelers' demands by showing the Qa'aba direction for prayer in their rooms. My event, the world Islamic Tourism Mart, is the ideal platform for tourism industry sectors to take part, meet, network, and create new opportunities to increase the capture of the Muslim tourism market [1].

UNWTO forecasted that in 2020 that Middle Eastern tourists will number 69 million with average annual growth rate is $6.7 \%$ (the highest among other region). This number of tourists is actually small but what matters is the Middle Eastern visitors are often affluent and are big spenders [3].

The Thai Government has offered many incentives for Muslim tourists to visit Thailand- Halal food, accommodation, mosques. We invite all Muslims around the world to spend the time to travel in Thailand. Muslim travelers can also travel from Thailand to all Asian countries This paper has focused on the halal tourism in Thailand. Halal tourism, that is, as permissible under Islam [2].

It is widely recognized that tourism plays an important role for regional development. Successful tourism can increase destination's tourist receipts, income, sustainable employment and government revenues. Thus, this leads to high competition among destinations on attracting tourist. Attract a new market segment is one among other strategies for tourism business to survive and prosper in this high competition. Muslim tourist gain high attention as the large niche market for tourism industry. Due to the fact that, among the top 20 countries that have had the greatest growth in international tourism expenditure $2005-2010,25 \%$ of that growth in expenditure is from OIC member countries. Thus, the significance of this growing source of international tourism from Muslim market is a key consideration for economies that have significant tourism revenues [1]. Since, the significant role of tourism in Thai economy has long been recognized, Thai government has granted various facilities to tourism agencies to develop other potential areas in the tourism industry, and developing Halal tourism is a promising approach to attract more tourists. However, there is a need for Thai community and tourism related sectors to understand the unique Muslim travel behavior and needs.

Hence, this study is aimed to examine Halal tourism management practices in the Andaman Sea coast of Thailand catering for travelers from Muslim countries. 


\section{LITERATURE REVIEW}

\section{A. Definition of Tourism}

Tourism is one of the most important and fast expanding sectors of the world economy [4]. It is also a major source of foreign exchange earnings for many developing countries. Tourism, because it has become such a large industry, has numerous impacts which can be felt and seen worldwide and that affect all forms of life. The effects of these impacts can be advantageous but they can also cause many disadvantages and bring many problems with them [5]. If tourism is managed properly (sustainable tourism), it can increase the benefits for or have positive impacts on the social and natural environment in the host area and reduce the negative effects significantly [4]. Tourism is defined by as follows: "Tourism comprises the activities of persons travelling to and staying in places outside their usual environment for not more than one consecutive year for leisure, business and other purposes not related to the exercise of an activity remunerated from within the place visited [4]. Tourism is different from travel. In order for tourism to happen, there must be a displacement: an individual has to travel, using any type of means of transportation he might even travel onfoot: nowadays, it is often the case for poorer societies, and happens even in more developed ones, and concerns pilgrims, hikers). But all travel is not tourism" [5].

\section{B. Halal Tourism}

Halal tourism is a new concept in the tourism industry. Thus, there a need to develop more halal tourism products and services to cater to this dynamic and emerging market [6]. The concept of halal, meaning permissible in Arabic, is not just being applied to food, but it includes any Shari'ah compliant products ranging from bank dealings to cosmetics, vaccines and in this case, tourism [6]. This means offering tour packages and destinations that are particularly designed to cater for Muslim considerations and address Muslim needs [7].

Halal Tourism integrates more religious conser-vative motivations, trying to valorize a conservative Islamic lifestyle and underline its incompatibility with Western type of tourism practices currently dominating the modern tourism industry [7]. The demand for halal resorts, hotels or transportation reveal's the reluctance of religious conservative families and Individuals to travel in liberal or western style locations and the condemnation of travel behaviors regarded as un - Islamic [1]. The hotels in such destinations tourists from all over the world offering facilities in accordance with the religious beliefs of Muslim tourists. Also, the halal tourism approach covers flights where no alcohol or pork products are served, prayer timings are announced, and religious programs are broadcast as part of entertainment offered on board [1].

Various factors influence tourist behavior; religion is one among others, such as the choice of destinations and tourism product preferences [2]. Muslim life is directed by the holy book of the Quran and the Sunnah or Hadith, containing the sayings and deeds of the Prophet Muhammad recalled by his companions and family [3]. Based on the Islamic worldview of God, man and nature, tourism is part of the region and travel is fundamental to Islam [4]. Even during traveling, Muslims are requested to respect fundamental Islamic precepts. The concept of halal, meaning permissible in Arabic, is not just being applied to food, but it includes any Shari'ah compliant products ranging from bank dealings to cosmetics, vaccines and in this case, tourism. This means offering tour packages and destinations that are particularly designed to cater for Muslim considerations and address Muslim needs [5]. Halal tourism integrates more religious conservative motivations, which try to valorize a conservative Islamic lifestyle and underline its incompatibility with Western type of tourism practices, which dominating the modern tourism industry. The demand for halal resorts, hotels or transportation reveals the reluctance of religious conservative families and individuals to travel in liberal or Western style locations and the condemnation of travel behaviors regarded as un-Islamic.

\section{Opportunities}

The Halal economy, which is rapidly expanding, offers opportunities to other Muslim countries worldwide. There is nearly 1.57 billion Muslims, in over 100 countries, making up over $23 \%$ of the total global population [1]. This will ensure that the halal concept can be applied to more than just the food sector. In addition, the manufacture, processing and distribution of products, additives and food ingredients, halal economy also applies to cosmetics, medicines and personal care products, clothes and services that include finance, hotels, restaurants and logistics. This statistics of the significant population of Muslims stress the enormous potential waiting to be tapped in the halal economy [8].

Regarding to the tourism sector, in Thailand, it is recognized as a major economic and social significance that contributes to the creation of wealth. As reported of Tourism Authority of Thailand, the tourism sector has been identified as a driver of economic activity that will contribute towards the growth and development of the economy [9]. The Thai Government has granted many incentives to tourism agencies to develop other promising areas in the tourism industry [2].

\section{Halal Tourism Business}

The fundamental of Halal tourism includes the components such as Halal hotel, Halal transportation, Halal food premises, Halal logistics, Islamic finance, Islamic travel packages, and Halal spa [8].

Halal hotel is one of the hotels which provide the Halal services to the Muslim tourists. This type of hotel is not limited to serve Halal food and beverages but the operation throughout the hotel would also be managed based on Islamic principles [7].

Halal food premises: Food and beverage products served in a restaurant have to be Halal. Animals such as chicken and cow must be slaughtered according to Shariah principles. All food must be Halal and go through Halal compliant process [5].

\section{E. Tourist Behavior}

The field of consumer behavior is a recent and young discipline which is form by contributions of many other disciplines such as sociology and economy in order to understand the way consumers behave (Blackwell et al. 
2006); tourist as well. It focuses on individuals making decisions about the use of their available resources (time, money and effort) in the purchase of goods and services related to consumption [10]. There are five stages of decision making: 1) need recognition; 2) information search and information acquisition; 3 ) evaluation of alternatives, which involves rating of options and leads to formation of preferences and formation of behavioral intentions; 4) actual purchase and consumption decision; and 5) post-purchase behaviors [11]. However, these five stages of consumer behavior are able to regroup into three categories, which are before purchase and consumption, during purchase and consumption, and after purchase and consumption [12], [13]. Thus, this study utilized this model to examine tourist behavior in three aspects, which are pre travel, during travel and after travel at Andaman Gulf, Thailand.

\section{Methodology}

The data for this study were collected from Muslim tourist in Andaman Gulf, Thailand, which consists of four provinces, namely; Krabi, Phuket, Pangna, and Satul. 60 tourists were participated this study. The survey was conducted from September to December 2011. The data were collected by using face-to-face with structure questionnaire. The questionnaire consisted of three parts. The first part dealt with personal characteristics of the respondents. Questions focused on respondents' gender, age, nationality, and income. The second part included questions of evaluate the potential of existing Halal tourist destinations. Regarding the evaluate, the respondents were asked to give opinions on a five-point Likert scale (1- Not at all important to 5 - very important). Content validity of these questionnaire items was evaluated by a professor from a tourism business school and a Halal expert. A pilot test was conducted to assess how well the instrument captured the constructs it was supposed to measure and to test the comprehension of the questionnaire items. The reliability of the measurements in this study was 0.84, which acceptable based on the Cronbach's alpha.

Applied research was used in this study to "find solutions to problems which arise in particular management situations" [9]. The sample group were government officers working in the tourism-related sections, administrators in the sub-district administrative organization offices in the provinces along the Andaman Sea coast, community leaders, tour guides, officers of the provincial offices of the Islamic Council in the Andaman Sea coast, sixty Muslim tourists from Muslim countries and officers of the Central Islamic Council of Thailand. The research instruments included a questionnaire, observations and focus group discussions.

\section{FINDINGS AND ANALYSIS}

The result from this study, concerning evaluation and rating of Halal tourist attraction potential, shows that the highest potential tourist attraction is Ao Nang $(\bar{x}=4.40)$, followed by the Phi Phi Island and Patong Beach $(\bar{x}=4.25)$, while the least potential one is the Tarutao National $\operatorname{Park}(\bar{x}=$ 3.65), (see Table I).
TABLE I: MEAN, STANDARD DEVIATION OF TOURISM PlaceS

\begin{tabular}{lcccc}
\hline \hline \multicolumn{1}{c}{ Tourism } & \multicolumn{2}{c}{$\boldsymbol{N = \mathbf { 1 5 }}$} & POTENTIA & \multirow{2}{*}{ LEVEL } \\
\hline Pestination & $\overline{\boldsymbol{x}}$ & S.D. & $\mathbf{L}$ & 2 \\
Ao Nang & 4.25 & 0.64 & High & 1 \\
Hot S & 4.40 & 0.58 & High & 3 \\
AoPangga & 4.19 & 0.46 & High & 6 \\
Molluse Fossil & 3.78 & 0.55 & Moderate & 4 \\
Promthep Cape & 4.18 & 0.64 & Moderate & 7 \\
Similan Island & 3.75 & 0.44 & Moderate & 5 \\
Patong Beach & 3.86 & 0.79 & Moderate & 2 \\
KohLipe & 4.25 & 0.75 & High & 5 \\
Tarutao National & 3.86 & 0.67 & Moderate & 8 \\
Park & 3.65 & 0.76 & Moderate & \\
\hline \hline
\end{tabular}

In examining Halal tourism management in the Andaman Sea coast of Thailand catering for travelers from Muslim countries, the research found that:

1) In terms of attractions, travelers from Muslim countries were interested in exploring natural forms of attractions, beaches and islands. Their typical activity included coral-diving and snorkelling

2) Regarding to amenities, prayer rooms should be provided for Muslim tourists since these are very essential especially for female tourists.

3) Regarding to transportation, tourists from Muslim countries indicated that the authorities should provide regular public buses or transportation to reach desired tourist attractions conveniently with reasonable fares.

4) Concerning safety (measures), Muslim tourists suggested that security guards or officers be stationed on the beaches at night so that they could take their wives and daughters for a walk safely.

5) Regarding to community participation, it was found that the community participation in tourism activities was limited because most of the tourist activities were in water.

6) Concerning food and beverages requirements, additional Halal restaurants should be provided and available in the tourist attractions with the certified Halal food logo.

For feasible guidelines on Halal tourism management in this area catering for travelers from Muslim countries, the findings suggested as follows:

1) The natural resources at the tourist attractions should be preserved for their natural beauty.

2) More tourism activities which are not against the Islamic obligations should be offered.

3) Prayer rooms should be provided for Muslim tourists as well as the direction signs to the local mosques either in English or Arabic.

4) Separate restrooms for men and women should be provided together with rinse spray hoses in hygienic conditions.

5) The Halal restaurants should be provided in tourist attraction areas.

6) The direction signs to tourist attractions in English should be provided.

7) Security measures should be enhanced in the tourist attractions especially at night. While providing services, tour guides and service staff should maintain discipline and respect Islamic obligations.

8) Safety-Tour boat drivers should operate the boats carefully with sufficient lifesaving devices for tourists. 
9) A welcome sign in Arabic should be placed at airports and important tourist attractions to impress the tourists from Muslim countries and make them feel welcomed to Thailand.

\section{CONClusion}

Halal tourism is a new business concept that has been initiated in order to cater for Muslim tourist needs when they are on vacation. The initiative for developing Halal tourism in Thailand will focus on providing Halal services when the Muslim tourists are traveling. Due to the demand from the Muslim market towards Halal services, it is essential for Thailand to develop a concept for Halal tourism to be enforced by the Government of Thailand. Furthermore, Halal tourism will directly fulfill the Muslim needs thus, it will become one of the critical niche product for the tourism industry in Thailand.

However, only a handful study examined evaluate the potential of existing Halal tourist destinations and Halal tourism management practices in the Andaman Sea coast of Thailand catering for travelers from Muslim countries. Thus, the results from this study provide the fundamental and meaningful information for policy makers and business sectors to effectively develop, promote and deliver products and services that meet the unique demand of this new market.

\section{ACKNOWLEDGMENTS}

The authors would like to thank the National Research Council of Thailand and Thailand Research Fund for supporting the study. In addition, the authors grateful for Asst. Prof. Supawadee Photiyarat, Director of Tourism and Hospitality Management Program for suggestions and all her help. . The authors also would like to thank Rajamangala Univeristy of Technology Srivijaya for supporting the time and facilities in conducting this research. Finally, I most gratefully acknowledge my parents and my friends for all their support throughout the period of this research.

\section{REFERENCES}

[1] H. Z. Farahani and J. C. Henderson, "Islamic tourism and managing tourism development in Islamic societies: the cases of Iran and Saudi Arabia," International Journal of Tourism Research, vol. 12, pp. 79-89, 2010.

[2] W. Saraithong and Chancharoenchai, "Tourists' behaviour in THAI homestay business," International Journal of Management Cases, pp. 112-127, 2010.

[3] TTR Weekly. (2013). Muslim market mushrooms. Filed under Europe. [Online]. Available: http://www.ttrweekly. com/site/2013/ 03/

[4] Ecological Tourism in Europe and UNESCO-BRESCE. (2009). Stainable Tourism Training the Trainers Programme. [Online]. Available:

http://www.unesco.org/new/en/venice/special-themes/sustainable-tour ism/

[5] M. G. Korres, "The role of innovation activities in tourism regional growth in Europe, tourisms," An International Multidisciplinary Journal of Tourism, vol. 3, no. 1, pp. 135-152, 2008.

[6] J. C. Henderson, "Sharia-compliant hotel," Tourism and Hospitality Research, vol. 10, no. 3, pp. 246-254, 2010.

[7] HALBASE PTE LTD. Halal Tourism. Working Paper. [Online]. Available: http://halbase.com/articles/Halal\%20Tourism.pdf

[8] R. R. Mohd, A. Uzzaini, and G. H. Mohamad. Developing a Model for Islamic Hotels: Evaluating Opportunities and Challenges. Universiti Utara Malaysia. Working Paper. [Online]. Available: http://www.ipedr.com/vol42/018-ICKC S2012-K10008

[9] A. J. Veal, Research Methods for Leisure and Tourism: A Practical Guide, $2^{\text {nd }}$ ed., London: Pitman, 1997.

[10] L. G. Schiffman and L. L. Kanuk. Consumer Behavior, $8^{\text {th }}$ ed. India: Prentice Hall, 2004.

[11] P. Kotler and K. L. Keller, Marketing Management, $13^{\text {th }}$ ed. Upper Saddle River, NJ: Prentice Hall, 2009.

[12] L. A. Manrai and A. K. Manrai, "Hofsted's cultural dimensions and tourist behaviors: A review and conceptual framework," Journal of Economics, Finance and Administrative Science, vol 16, no. 31, pp 23-48, 2001.

[13] C. Williams and J. Buswell, Service Quality in Leisure and Tourism, UK: CABI Publishing, 2003.

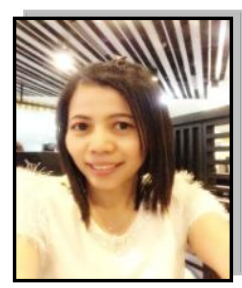

Oraphan Chanin was born in Songkla, Thailand. She holds a master degree in industrial management from King Mongkut's University of Technology North Bangkok and received her Ph.D. in management from Universities Utara of Malaysia, Kedah, Malaysia in 2010. She is a lecturer of management faculty of Business Administration Rajamangala University of Technology Srivijaya, Thailand. Her areas of research interest include management, entrepreneurship, tourism and strategy management. 